\title{
Meta-Analysis the Effect of Section Caesarea on Early Breastfeeding Initiation
}

\author{
Ferda Fibi Tyas Nurkholifa'), Eti Poncorini Pamungkasari²), Hanung Prasetya3) \\ 1)Masters Program in Public Health, Universitas Sebelas Maret \\ 2)Faculty of Medicine, Universitas Sebelas Maret \\ ${ }^{3)}$ Study Program of Acupuncture, Health Polytechnics, Ministry of Health Surakarta
}

\section{ABSTRACT}

Background: Early Initiation of Breastfeeding is the baby's first activity to find the mother's nipple within the first hour of birth. UNICEF and WHO recommend Early Breastfeeding Initiation as a strategy to achieve the 4th MDG, namely reducing child mortality. Early Breastfeeding Initiation has many benefits but its prevalence is still low, one of the contributing factors is cesarean section delivery. This study aims to estimate the effect of cesarean section delivery on early breastfeeding initiation based on the results of a number of previous studies.

Subjects and Method: This study was a meta-analysis and systematic study. The articles used were obtained from PubMed, Science Direct and Google Scholar published from 2009-2020. The inclusion criteria used were full text articles with observational designs, articles published in English and Indonesian. The PICO study problems are as follows. Population $=$ post partum mothers. Intervention $=$ cesarean section delivery. Comparison $=$ normal delivery. Outcome $=$ early initiation of breastfeeding. Articles were collected using a prism flow diagram. Meta analysis was performed using RevMan 5.3 with a Random Effect Model.

Results: A total of 11 articles conducted a meta-analysis review of this study. The metaanalysis of 11 articles showed that women who gave birth through cesarean section technique were 0.33 times more likely to have early breastfeeding initiation compared to normal delivery. $(\mathrm{aOR}=0.33 ; 95 \% \mathrm{CI}=0.18$ to 0.59 ; $\mathrm{p}<0.001)$.

Conclusion: Mothers who gave birth through cesarean section technique were more likely to initiate early breastfeeding by 0.33 times compared to normal delivery.

Keywords: caesarean section, delivery method, early initiation of breastfeeding

\section{Correspondence:}

Ferda Fibi Tyas Nurkholifa. Masters Program in Public Health, Universitas Sebelas Maret, Surakarta, Jl. Ir. Sutami 36A, Surakarta 57126, Central Java, Indonesia. Email: ferdafibi13@gmail.com. Mobile: +6285655778863 .

\section{Cite this as:}

Nurkholifa FFT, Pamungkasari EP, Prasetya H (2021). Meta-Analysis the Effect of Section Caesarea on Early Breastfeeding Initiation. J Matern Child Health. 06(01): 46-55. https://doi.org/10.26911/thejmch.2021.06.01.05.

\section{BACKGROUND}

Initiation of Breastfeeding is the primary intervention for survival of the newborn during the perinatal period. The World Health Organization (WHO) recommends putting newborns in direct contact with the mother immediately after birth to encourage Early Initiation of Breastfeeding for at least 1 hour (Khanal et al., 2015).

The United Nation of children's fund (UNICEF) and the World Health Organization (WHO) have promoted Early Initiation of Breastfeeding in the first hour of a baby's birth. This is done as an important strategy in reducing disability and mortality 
for perinatal and children under 2 years old in order to support the achievement of the 4th Millennium Development Goal (MDGs), namely reducing child mortality. In supporting the campaign carried out by WHO, health workers played a big role in the realization of the Early Breastfeeding Initiation (Lutter, 2010).

Early Initiation of Breastfeeding has benefits for both mother and newborn. Early Initiation of Breastfeeding can stimulate milk production and facilitate the release of prolactin and oxytocin stimulated by the nipple suction by the baby. Early Initiation of Breastfeeding stimulates uterine contractions after delivery and reduces the risk of postpartum hemorrhage. In addition, Early Initiation of Breastfeeding encourages mothers to provide further breastfeeding to the baby so that breastfeeding can prolong the period of postpartum infertility, help mothers return to pre-natal weight, reduce the risk of breast cancer and ovarian cancer and Type-2 Diabetes (UNICEF, 2018).

For infants, early initiation of breastfeeding helps to get the first breast milk, namely colostrum. Colostrum is very nutritious and has antibodies that protect newborns from disease. Therefore, it is important for newborn's health to immediately initiate early breastfeeding. The practice of Early Initiation of Breastfeeding is considered to be capable of stimulating the immunoglobulins and lymphocytes found in colostrum to prevent pathogenic infections during normal intestinal maturation to protect the baby from diarrhea. Early Initiation of Breastfeeding can also prevent hypothermia in newborns (Exavery, 2020). Breastfeeding has been shown to be associated with a reduced risk of Sudden Infant Death Syndrome (SIDS), otitis media, respiratory tract infections, gastroenteritis, asthma, atopic dermatitis, type 2 diabetes, and obesity (WHO, 2014).
The low level of early initiation of breastfeeding can be attributed to several factors, however, in broad terms, it is classified based on maternal factors, infant factors and environmental factors. Studies in various countries has shown that maternal factors such as age, parity, ethnicity, education level, employment, maternal knowledge about EBI, nutritional status, method of delivery, duration of labor, experience of childbirth and experience of breastfeeding significantly affect the practice of EBI (Mullany et al., 2008).

In 2017, an estimated 78 million newborns were still not breastfed within 1 hour of birth (UNICEF, 2018). Based on a survey in Asia, the achievement of Early Initiation of Breastfeeding is only $41 \%$ of total births in the first hour of birth. Several countries in South Asia have the worst practices of Early Initiation of Breastfeeding in the world. These countries include 29\% of infants in Pakistan, $41 \%$ of babies in India, $47 \%$ of babies in Bangladesh and $45 \%$ of babies in Nepal (Sharma et al., 2016). In fact, in several countries in Africa such as Nigeria and Ethiopia, the prevalence of EBI is still low. The prevalence of a national study conducted in Nigeria reports a low rate for Early Initiation of Breastfeeding, which is around $31.9 \%$ (Berde, 2016). Meanwhile, in Ethiopia, 39\% of newborns received Early Initiation of Breastfeeding (Mekonen, 2018).

Several studies have been conducted to determine the effect of cesarean section delivery on early breastfeeding initiation, one of them is a study by Gayatri et al (2020) concluded that labor by cesarean section affects Early initiation of breastfeeding by 0.47 times higher compared to normal delivery.

A study by Aroraet al., (2018) reported that labor by cesarean section affects early initiation of breastfeeding by 
o.2 times higher compared to normal delivery.

This is reinforced by Islam et al (2019), which stated that labor by cesarean section affects early initiation of breastfeeding by 0.06 times higher compared to normal delivery.

The low initiation of early breastfeeding caused by cesarean section delivery which is supported by several studies encourages researchers to combine and analyze existing study results and draw conclusions from studies that discuss the effect of cesarean section delivery on early breastfeeding initiation.

\section{SUBJECTS AND METHOD}

\section{Study Design}

This study is a systematic review and metaanalysis study. The articles used in this study were obtained from several databases including PubMed, Science Direct, and Google Scholar. The keywords for finding articles are as follows: "caesarean section" AND "early initiation of breastfeeding" OR "delivery method" AND "early initiation of breastfeeding", "early initiation of breastfeeding" AND "cross sectional".

\section{Inclusion Criteria}

The articles included in this study were full text articles with a cross sectional study design, cesarean section delivery research interventions with early breastfeeding initiation outcomes and the articles used in this study were published in English and Indonesian.

\section{Exclusion Criteria}

The articles published in this study were articles with random controlled trial, case control, quasi experiment, protocol study and pilot study design. The articles were not published in English and Indonesian. The statistical results reported were not AOR. The AOR results obtained were overestimated and the 95\% CI was too wide.

\section{Operational Definition of Variables}

The article search was carried out by considering the eligibility criteria defined using the PICO model. The population in the study was post partum mothers with intervention in the form of cesarean section delivery, comparison, namely normal delivery and outcomes in the form of early breastfeeding initiation.

Cesarean Section Delivery is a type of delivery using the surgical method of surgery. The instrument used was a questionnaire with a categorical measuring scale.

Early Breastfeeding Initiation is an activity in which the baby breastfeeds immediately after birth by looking for the mother's nipple for one hour. The instrument used was a questionnaire with a categorical measuring scale.

\section{DataAnalysis}

Data processing was carried out by the Review Manager (RevMan 5.3) by calculating the effect size and heterogeneity to determine which study model was combined and formed the final meta-analysis result.

\section{RESULTS}

The process of searching for articles by searching through a database with journals can be seen in Figure 1.

Figure 2 shows the areas where articles were drawn according to the inclusion criteria. Articles obtained from 4 continents, namely Asia, Europe, Africa and America. 
Nurkholifa et al./ The Effect of Section Caesarea on Early Breastfeeding Initiation

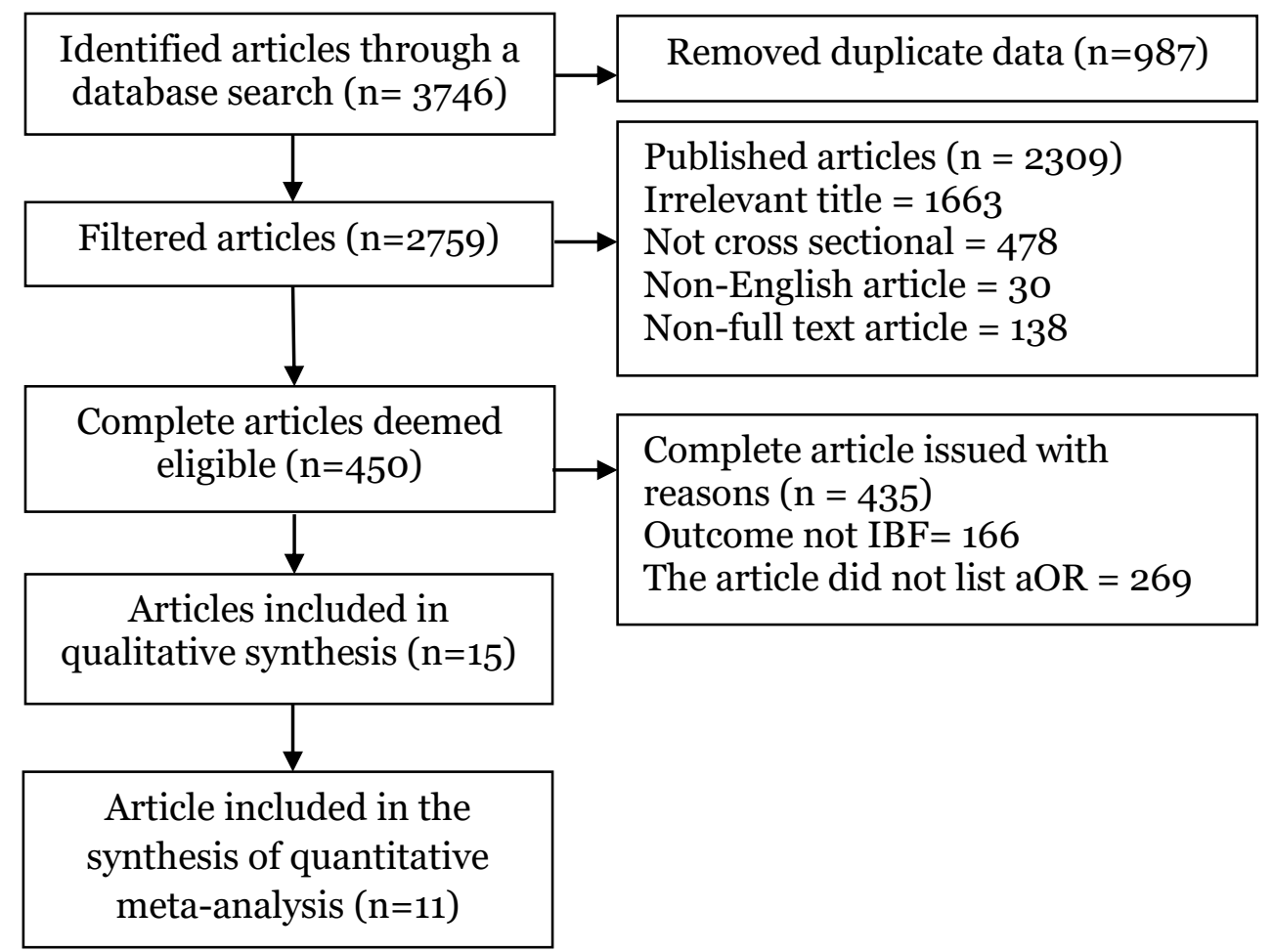

Figure 1. PRISMA flow diagram

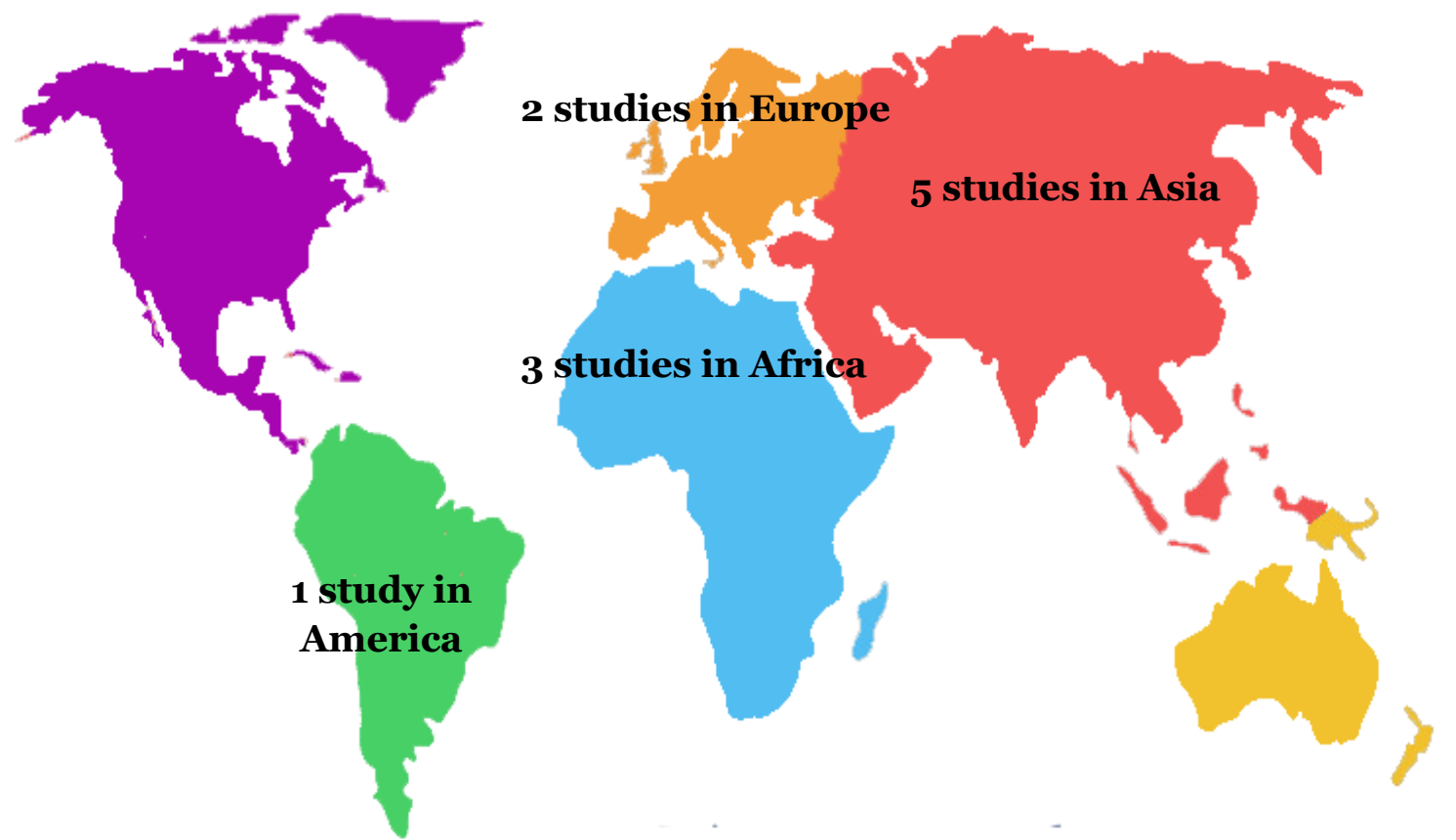

Figure 2. Map of the area 
1. Summary Source

Table 1. Description of primary studies included in the meta-analysis of Effect of Caesarean Section Delivery on Early Breastfeeding Initiation

\begin{tabular}{|c|c|c|c|c|c|c|c|}
\hline $\begin{array}{l}\text { Author } \\
\text { (year) }\end{array}$ & Country & $\begin{array}{l}\text { Study } \\
\text { Design }\end{array}$ & Sample & $\mathbf{P}$ & $\mathbf{I}$ & $\mathbf{C}$ & $\mathbf{O}$ \\
\hline $\begin{array}{l}\text { Islam et al. } \\
(2019)\end{array}$ & Bangladesh & $\begin{array}{l}\text { Cross } \\
\text { sectional }\end{array}$ & 4,092 & $\begin{array}{l}\text { Postpartum } \\
\text { mother }\end{array}$ & $\begin{array}{l}\text { Caesarean section delivery }{ }^{*} \text {, } \\
\text { urban life, overweight mother }\end{array}$ & $\begin{array}{l}\text { Normal delivery*, living in } \\
\text { rural areas, the normal } \\
\text { maternal weight }\end{array}$ & $\begin{array}{l}\text { Early Initiation of } \\
\text { Breastfeeding }\end{array}$ \\
\hline $\begin{array}{l}\text { Karim et al. } \\
(2019)\end{array}$ & Bangladesh & $\begin{array}{l}\text { Cross } \\
\text { sectional }\end{array}$ & 3,162 & $\begin{array}{l}\text { Postpartum } \\
\text { mother }\end{array}$ & Caesarean section delivery * & Normal delivery ${ }^{*}$ & $\begin{array}{l}\text { Early Initiation of } \\
\text { Breastfeeding }\end{array}$ \\
\hline $\begin{array}{l}\text { Lok et } \\
\text { al.(2015) }\end{array}$ & $\begin{array}{l}\text { Hong Kong } \\
\text { and } \\
\text { Mainland } \\
\text { China }\end{array}$ & $\begin{array}{l}\text { Cross } \\
\text { sectional }\end{array}$ & 2,761 & $\begin{array}{l}\text { Postpartum } \\
\text { mother }\end{array}$ & $\begin{array}{l}\text { Caesarean section delivery }{ }^{*} \text {, } \\
\text { the mother smokes, there is a } \\
\text { problem with pregnancy, the } \\
\text { baby has LBW }\end{array}$ & $\begin{array}{l}\text { Normal delivery }{ }^{*} \text {, the } \\
\text { mother does not smoke, } \\
\text { there are no problems } \\
\text { during pregnancy, the baby } \\
\text { has normal weight }\end{array}$ & $\begin{array}{l}\text { Early Initiation of } \\
\text { Breastfeeding }\end{array}$ \\
\hline $\begin{array}{l}\text { Seidu et al. } \\
(2020)\end{array}$ & $\begin{array}{l}\text { Papua New } \\
\text { Guenea }\end{array}$ & $\begin{array}{l}\text { Cross } \\
\text { sectional }\end{array}$ & 3,198 & $\begin{array}{l}\text { Postpartum } \\
\text { mother }\end{array}$ & Caesarean section delivery * & Normal delivery * & $\begin{array}{l}\text { Early Initiation of } \\
\text { Breastfeeding }\end{array}$ \\
\hline $\begin{array}{l}\text { Gayatri et } \\
\text { al. (2020) }\end{array}$ & Indonesia & $\begin{array}{l}\text { Cross } \\
\text { sectional }\end{array}$ & 6,616 & $\begin{array}{l}\text { Postpartum } \\
\text { mother }\end{array}$ & Caesarean section delivery $*$ & Normal delivery * & $\begin{array}{l}\text { Early Initiation of } \\
\text { Breastfeeding }\end{array}$ \\
\hline $\begin{array}{l}\text { Tarrant et } \\
\text { al. (2009) }\end{array}$ & Ireland & $\begin{array}{l}\text { Cross } \\
\text { sectional }\end{array}$ & 491 & $\begin{array}{l}\text { Postpartum } \\
\text { mother }\end{array}$ & Caesarean section delivery ${ }^{*}$ & Normal delivery * & $\begin{array}{l}\text { Early Initiation of } \\
\text { Breastfeeding }\end{array}$ \\
\hline $\begin{array}{l}\text { Warren et } \\
\text { al. (2014) }\end{array}$ & Ireland & $\begin{array}{l}\text { Cross } \\
\text { sectional }\end{array}$ & 1,715 & $\begin{array}{l}\text { Postpartum } \\
\text { mother }\end{array}$ & $\begin{array}{l}\text { Caesarean section delivery }{ }^{*} \text {, } \\
\text { premature gestational age }\end{array}$ & $\begin{array}{l}\text { Normal delivery *, full term } \\
\text { gestational age }\end{array}$ & $\begin{array}{l}\text { Early Initiation of } \\
\text { Breastfeeding }\end{array}$ \\
\hline $\begin{array}{l}\text { Exavery et } \\
\text { al. (2015) }\end{array}$ & Tanzania & $\begin{array}{l}\text { Cross } \\
\text { sectional }\end{array}$ & 889 & $\begin{array}{l}\text { Postpartum } \\
\text { mother }\end{array}$ & Caesarean section delivery * & Normal delivery * & $\begin{array}{l}\text { Early Initiation of } \\
\text { Breastfeeding }\end{array}$ \\
\hline $\begin{array}{l}\text { Libenet al. } \\
\text { (2016) }\end{array}$ & Ethiopia & $\begin{array}{l}\text { Cross } \\
\text { sectional }\end{array}$ & 407 & $\begin{array}{l}\text { Postpartum } \\
\text { mother }\end{array}$ & Caesarean section delivery * & Normal delivery * & $\begin{array}{l}\text { Early Initiation of } \\
\text { Breastfeeding }\end{array}$ \\
\hline $\begin{array}{l}\text { Tilahunet } \\
\text { al. (2016) }\end{array}$ & Ethiopia & $\begin{array}{l}\text { Cross } \\
\text { sectional }\end{array}$ & 416 & $\begin{array}{l}\text { Postpartum } \\
\text { mother }\end{array}$ & $\begin{array}{l}\text { Caesarean section delivery *, } \\
\text { not given EBI counseling at } \\
\text { ANC }\end{array}$ & $\begin{array}{l}\text { Normal delivery *, got EBI } \\
\text { counseling at ANC }\end{array}$ & $\begin{array}{l}\text { Early Initiation of } \\
\text { Breastfeeding }\end{array}$ \\
\hline $\begin{array}{l}\text { Vasquezet } \\
\text { al. (2019) }\end{array}$ & Peru & $\begin{array}{l}\text { Cross } \\
\text { sectional }\end{array}$ & 34,971 & $\begin{array}{l}\text { Postpartum } \\
\text { mother }\end{array}$ & Caesarean section delivery * & Normal delivery * & $\begin{array}{l}\text { Early Initiation of } \\
\text { Breastfeeding }\end{array}$ \\
\hline
\end{tabular}


Nurkholifa et al./ The Effect of Section Caesarea on Early Breastfeeding Initiation

\section{Study Quality Assessment}

Assessment of Study Quality using the Critical Appraisal CEBM (Center For Evidence-Based Medicine) which consists of 12 questions as follows:

a. Does this objective clearly address the focus/studyproblem?

b. Is the study method (study design) suitable for answering research questions?

c. Is the method of selecting study subjects clearly written?

d. Can the sampling method introduce bias (selection)? e. Does the study sample taken represent the designated population?

f. Is the sample order based on pre-study considerations?

g. Is a satisfactory response achieved?

h. Are the study instruments valid and reliable?

i. Is statistical significance assessed?

j. Are confidence intervals given for the main outcome?

$\mathrm{k}$. Are there any confounding factors that haven't been taken into account?

1. Are the results applicable to your study?

Table 2. Assessment of the Quality of Study on the Effect of Caesarean Section Delivery on Early Breastfeeding Initiation

\begin{tabular}{|c|c|c|c|c|c|c|c|c|c|c|c|c|c|}
\hline \multirow{2}{*}{ Primary Study } & \multicolumn{12}{|c|}{ Criteria } & \multirow{2}{*}{ Total } \\
\hline & $\mathbf{1}$ & 2 & 3 & 4 & 5 & 6 & 7 & 8 & 9 & 10 & $\mathbf{1 1}$ & 12 & \\
\hline Islam et al. (2019) & 1 & 1 & 1 & 1 & 1 & $\mathrm{O}$ & 1 & 1 & 1 & 1 & 1 & 1 & 11 \\
\hline Karim et al. (2019) & 1 & 1 & 1 & 1 & 1 & 1 & 1 & 1 & 1 & $\mathrm{O}$ & 1 & 1 & 10 \\
\hline Lok et al.(2015) & 1 & 1 & 1 & 1 & 1 & $\mathrm{O}$ & 1 & 1 & 1 & $\mathrm{O}$ & 1 & 1 & 10 \\
\hline Seiduet al. (2020) & 1 & 1 & 1 & 1 & 1 & $\mathrm{O}$ & 1 & 1 & 1 & $\mathrm{O}$ & 1 & 1 & 10 \\
\hline Gayatriet al. (2020) & 1 & 1 & 1 & 1 & 1 & 1 & 1 & 1 & 1 & 1 & 1 & 1 & 12 \\
\hline Tarrantet al. (2009) & 1 & 1 & 1 & 1 & 1 & 1 & 1 & 1 & 1 & 1 & 1 & 1 & 12 \\
\hline Warren et al. (2014) & 1 & 1 & 1 & 1 & 1 & $\mathrm{O}$ & 1 & 1 & 1 & O & 1 & 1 & 10 \\
\hline Exavery et al. (2015) & 1 & 1 & 1 & 1 & 1 & 1 & 1 & 1 & 1 & 1 & 1 & 1 & 12 \\
\hline Libenet al. (2016) & 1 & 1 & 1 & 1 & 1 & 0 & 1 & 1 & 1 & 0 & 1 & 1 & 10 \\
\hline Tilahunet al. (2016) & 1 & 1 & 1 & 1 & 1 & $\mathrm{O}$ & 1 & 1 & 1 & 1 & 0 & 1 & 12 \\
\hline Vasquezet al. (2019) & 1 & 1 & 1 & 1 & 1 & 1 & 1 & 1 & 1 & 1 & 1 & 1 & 12 \\
\hline
\end{tabular}

Information:

$1=$ Yes

$0=$ No

\section{Forest Plot}

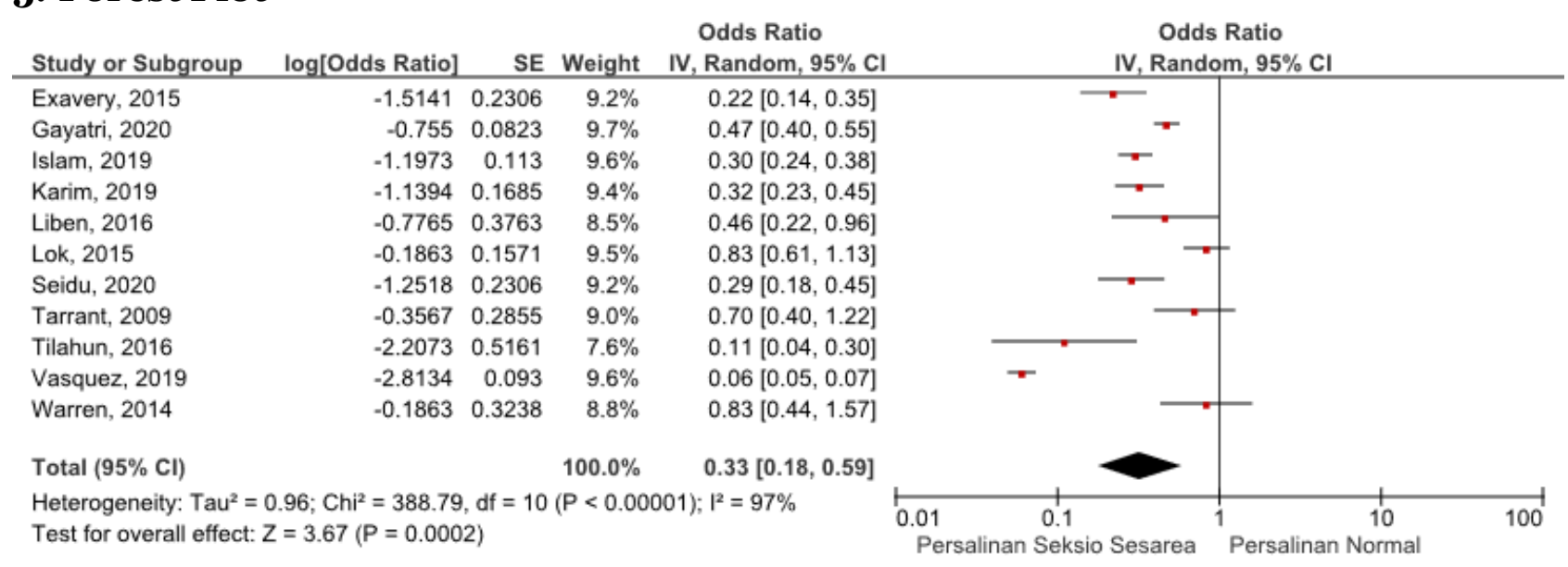

Figure 3. Forest plot of meta-analysis of the effect of Caesarean Section Delivery on Early Breastfeeding Initiation 
Based on the results of the analysis in Figure 3, it can be seen that there were 11 articles showing that mothers who gave birth with cesarean section technique have

\section{Funnel Plot}

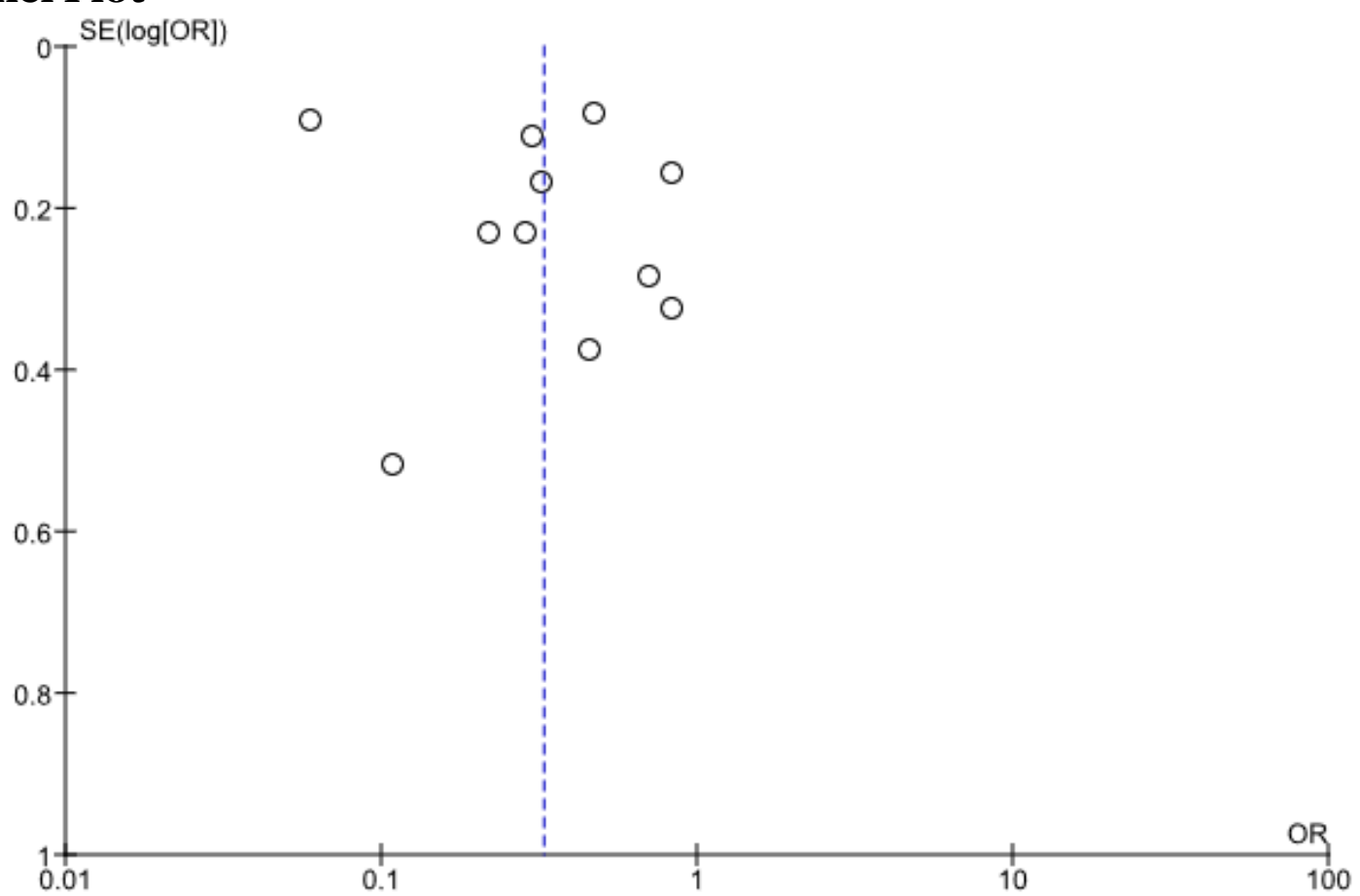

Figure 5. Funnel plot of meta-analysis of the effect of Caesarean Section Delivery on Early Breastfeeding Initiation

Figure 5 showed that there was no publication bias which was indicated by symmetrical plots on the right and left, where 5 plots were on the right and 4 plots on the left and 2 plots right on the line between the right and left plots.

\section{DISCUSSION}

Study related to the effect of cesarean delivery on Early Initiation of Breastfeeding consisted of 11 primary research articles spread over 4 continents, namely Asia, Europe, Africa and America from India, Nepal, Bangladesh, Malaysia, Indonesia, Australia, Mexico, Ethiopia and 4 temperatures. articles from India, Taiwan, Australia and the United States.

Research that addresses data on early initiation of breastfeeding is considered the possibility to initiate early breastfeeding by 0.33 times higher compared to normal delivery ( $\left.\mathrm{I}^{2}=97 \% ; \mathrm{p}<0.001\right)$ so that the Random Effect Model was used (BRAKE). important because of its reduction or delay. The number of relevant research published and accessible is still small and also has data access problems (data duplication) (Murti, 2018). Most of the statistical results reported are in the total percentage or crude odd ratio (cOR), where the study did not control for confounding factors.

The results of the systematic study and meta-analysis are presented in the form of a forest plot and a funnel plot. Forest plots provide an overview of the information from each of the studies examined in the meta-analysis, and estimates of the overall results (Murti, 2018). The forest plot shows visually the amount of variation (heterogeneity) between study results (Akobeng in Murti, 2018). 
A funnel plot is a diagram in a metaanalysis used to demonstrate possible publication bias. The funnel plot shows the relationship between the effect size of the study and the sample size or standard error of the effect size of the various studies studied (Murti, 2018).

The funnel plot shows visually the amount of variation (heterogeneity) (Akobeng, 2005 in Murti, 2018). The funnel plot shows the relationship between the effect size of the study and the sample size of the various studies under study, which can be measured in a number of different ways (Murti, 2018).

\section{Caesarean section delivery to early initiation of breastfeeding}

The results of a meta-analysis of 11 articles on the effect of cesarean delivery on early breastfeeding initiation were summarized in the forest plots. The forest plot in Figure 4.3 shows that the type of cesarean section delivery were 0.33 times more likely to experience delay in early initiation of breastfeeding compared to the normal type of delivery. These results were statistically significant $(\mathrm{aOR}=0.33$; CI 95\%= 0.18 to 0.59; $\mathrm{p}<0.001)$.

This is supported by Islam et al., (2019) which stated that cesarean delivery had a decrease in early initiation of breastfeeding, which was caused by factors where the mother lived and the mother was overweight. Mothers who live in urban areas tend to choose the method of cesarean delivery. For overweight and obese women with a high BMI, the indications for cesarean section delivery are higher. The choice of the method of delivery by section should reduce the initiation of early breastfeeding because the mother is tired and the effects of anesthesia have not gone.

This study is in line with Lok et al., (2015) which stated that the decrease or delay in early initiation of breastfeeding is caused by mothers who smoke, pregnancy problems suffered by mothers in choosing the type of delivery and the condition of babies with LBW. In cesarean delivery with LBW babies, it will cause separation of the baby in which the baby must be immediately taken to the neonatal care unit to be given immediate care. This separation of the baby and the mother lead to a delay in early initiation of breastfeeding.

The findings from Gayatri et al., (2020) also show that mothers who give birth by cesarean section are less likely to start breastfeeding early. This is consistent with similar findings in other countries. Cesarean section delivery results in prolonged mother-infant separation, maternal endocrinological changes caused by cesarean section and stressful conditions for the woman, who also need time to recover from the effects of anesthesia. In addition, babies born by cesarean section may have respiratory problems so they can be taken to the newborn intensive care unit. Therefore, mothers with cesarean delivery are recommended to receive specialized counseling in breastfeeding and support from trained providers on proper breastfeeding. Furthermore, provide adequate support and guidance from trained health workers in the early postnatal period so as to increase early breastfeeding initiation among mothers who give birth by cesarean section.

Another study conducted by Liben et al., (2016) stated that mothers who gave birth by cesarean section were less likely to start breastfeeding within 1 hour of birth compared to those who gave birth by normal delivery. Likewise, cesarean section delivery is a barrier to early initiation of breastfeeding in Saudi Arabia, India and Nepal. This may be explained because mothers who deliver their children by cesarean section take longer to recover from the effects of anesthesia. This can lead 
to a longer delay in making first contact with their baby, and mothers may also have difficulty in achieving a comfortable breastfeeding position. In addition, babies born by cesarean section may experience respiratory problems. Therefore, they will most likely be taken to the newborn intensive care unit and physically separated from the mother.

This is reinforced by Tilahun et al., (2016) which stated that cesarean section delivery causes a decrease in early breastfeeding initiation due to obstetric indications in mothers or babies, fatigue in mothers and the effect of anesthesia that has not disappeared and lack of maternal education are also some of the factors which strengthens cesarean section delivery in reducing early initiation of breastfeeding. There are indications that the mother or baby makes health workers busy in saving the mother or fetus so that the separation of the mother and baby results in a decrease in early breastfeeding initiation.

However, there are several weaknesses in this study including search bias because in this study, the researcher only used 3 databases, namely PubMed, Google Scholar and Science Direct so that other search sources were ignored, there was also language bias because this study only used articles published in English and Indonesian so that articles in other languages were ignored.

Based on the results of studies conducted in 11 primary studies, it can be concluded that mothers who give birth using cesarean section technique have the possibility of initiating early breastfeeding by 0.33 times higher compared to normal delivery.

\section{AUTHOR CONTRIBUTION}

Ferda Fibi Tyas Nurkholifa is the main researcher who selected topics, searched and collected study data. Eti Poncorini Pamungkasari and Hanung Prasetya have a role in analyzing the data to review study documents.

\section{CONFLICT OF INTEREST}

There is no conflict of interest in this study.

FUNDING AND SPONSORSHIP

This study is self-funded.

\section{ACKNOWLEDGEMENT}

We are very grateful to the database providers of PubMed, Google Scholar and Science Direct.

\section{REFERENCE}

Arora A, Narendar M, Andrew H, Sameer B, John E, Steven L, Jane AS (2017). Determinants of breastfeeding initiation among mothers in Sydney, Australia: Finding from a birth cohort study. Int Breastfeeding J. 12:39.

Berde AS, Siddika SY. (2016). Determinants of early breastfeeding in Nigeria: A population-based study using the 2013 demographic and health survey data. BMC Pregnancy Childbirth 16:32.

CEBMa. (2014). Critical Appraisal Checklist for Cross-Sectional Study. Center for Evidence Based Management, https://www.cebma.org.

Exavery A, Almamy MK, Ahmd H, James FP (2015). Determinants of early initiation of breastfeeding in rural Tanzania. Int Breastfeeding J. 10:27.

Gayatri M, Gourange LD (2020). Predictors of early initiation of breastfeeding in Indonesia: A Population Based Cross Sectional Survey. PLoS ONE 15(9).

Islam A, Asma M, Murad H, Premnanda B, Aik S, Pete EL, Golam H (2019). Prevalence and factors associated with early initiation of bresatfeeding among Bangladeshi mothers: A 
Nurkholifa et al./ The Effect of Section Caesarea on Early Breastfeeding Initiation

nationwide cross-sectional study. PLoS ONE 14(4).

Karim F, Abdullah NSK, Fariha T, Mohiuddin AKC, Masum Billah, Sharma EA, Sarah PG (2019). Prevalence and determinants of initiation of breastfeeding within one hour of birth: An Analysis of the Bangladesh Demographic and Health Survey, 2014. PloS ONE 14(7).

Khanal V, Scott J, Lee A, Karkee R, Binns C, (2015). Factors associated with Early Initiation of Breastfeeding in Western Nepal. Int $J$ Environ Res Public Health. 12: 9562-9574.

Liben LM, Ebrahim MY (2016). Determinants of early initiation of breastfeeding in Amibara District, Northeastern Ethiopia: A Community Based CrossSectional Study. Int Breastfeeding J. 11: 7 .

Lok KYW, Dorothy LB, Marie T (2015). Predictors of breastfeeding initiation in Hong Kong and Mainland China born mothers. BMC Pregnancy Childbirth. 15: 286.

Lutter C (2010). Early initiation of breastfeeding: Key to survival and beyond. Washington DC: Rev Panam Salud Publica.

Mekonen L, Wubareg S, Zemenu S (2018). Timely initiation of breastfeeding and associated factors among mothers of infants under 12 months in South Gondar Zone, Amhara Regional State, Ethiopia; 2013. Int Breastfeeding J. 13: 17.

Mullany LC, Katz J, Li YM, Khatry SK, LeClerq, Darmstadt GL, et al. (2008). Breast-feeding patterns, time to initiation, and mortality risk among newborns in Southern Nepal. J nutr. 138(8): 599-603.

Murti B (2018). Prinsip dan Metode Riset Epidemiologi. Edisi ke 5 (Epidemiolo- gical Research Principles and Methods. 5th edition). Surakarta: Program Studi Ilmu Kesehatan Masyarakat.

Seidu AS, Bright OA, Ebenezer A, Louis KD, Justice KT, Edward KA, Tarif S (2020). Determinants of early initiation of breastfeeding in Papua New Guenea: A population-based study using the 2016-2018 demographic and health survey data. Arch Public Health 78:124.

Sharma B. (2016). Early initiation of breastfeeding: a systematic literature review of factors and barriers in South Asia. Int.Breastfeeding.J.1 -11.

Tarrant RC, Katherine MY, Margaret SP, Marlin JW, John MK (2009). The prevalence and determinants of breast-feeding initiation and during in a sample of woman in Ireland. Public Helath Nutr. 13(6): 760-770.

Tilahun G, Getu D, Askal T (2016). Prevalence and associated factors of timely initiation of breastfeeding among mothers at Debre Berhan Town, Ethiopia: A cross-sectional study. Int Breastfeeding J. 11:27.

United Nations Children's Fund (UNICEF. (2018). Capture the moment early initiation of breastfeeding: The best start for every newborn. New York: UNICEF.

Vasquez AH, Horacio CT (2018). Determinants of early initiation of breastfeeding in Peru: Anlysis of the 2018 demographic and family health survey. Epidemiology and Health. 41.

Warren PL, Helen M, Paul C. Factors influencing initiation ad duration of breastfeeding in Ireland. Midwifery 30: 345-352.

WHO (2014). Infant and Young Child Feeding. WHO Press: Geneva. 
Nurkholifa et al./ The Effect of Section Caesarea on Early Breastfeeding Initiation 